\title{
Selected Issues of Legislation with regard to Operating Pharmacies in the Slovak Republic Vybrané problémy právnej úpravy prevádzkovania lekární v podmienkach Slovenskej republiky
}

Abstract Among the basic rights and freedoms, stipulated in the Constitution of the Slovak Republic, are right to protection of health, free medical care based on health insurance, right to medical aids under conditions stipulated by law. These rights are guaranteed through provisions of Art. 40 of the Constitution of the Slovak Republic as part of Economic, Social and Cultural Rights and they apply to every individual. Since these rights are considered to be human rights under the international law, they are guaranteed by multilateral treaties in which Slovak Republic is a signatory, such as International Covenant on Economic, Social and Cultural Rights.

Legal regulation of operating pharmacies in the Slovak Republic covers a broad scope of issues and is quite extensive. Through concerted legislative effort, the legislator had tried to set rules that would make the legal environment in this sector more transparent and easier to navigate through. In some areas, the rules were set by the legislature of the European Union (EU) and the Slovak legislature only adapted them. The most important aspect of legal regulation in this sphere that is not completely regulated by the EU legislature is providing pharmaceutical care and usage of the public health insurance system with regard to providing pharmaceutical care.

The main aim of this study is to point out select issues that are associated with the position of a pharmacy operator and obligations stipulated in the Medicines Act 2011 that must be observed and incorporated into the running of a pharmacy. This area of business is fairly strictly regulated and therefore it is necessary to get acquainted with the relevant legislation. The study addresses several issues regulated by the Medicines Act 2011 or the Appropriate Pharmaceutical Practice Regulation 2012 from the legal-theoretical perspective.

Slovak Medzi základné práva a slobody, upravené v druhej hlave Ústavy Slovenskej republiky patrí aj právo na ochranu zdravia abstract bezplatnú zdravotnú starostlivost' na základe zdravotného poistenia, právo na zdravotnícke pomôcky za zákonom stanovených podmienok. Tieto práva sú garantované v ustanovení Čl. 40 Ústavy Slovenskej republiky v rámci ekonomických, sociálnych a kultúrnych práv a vztahujú sa na každú fyzickú osobu, t. j. na človeka. Kedže sú tieto práva považované za ludské práva v zmysle medzinárodného práva, sú garantované aj v mnohostranných medzinárodných zmluvách, ktorých signatárom je aj Slovenská republika, ako napríklad Medzinárodný pakt o hospodárskych, sociálnych a kultúrnych právach.

Právna úprava prevádzkovania lekární v Slovenskej republike zahŕňa široké spektrum otázok a je pomerne rozsiahla. Snahou zákonodarcu bolo nastavit také pravidlá, ktoré by stransparentnili a zjednodušili právne prostredie v tomto sektore. V niektorých oblastiach sú pravidlá dané legislatívou Európskej únie a slovenský právny poriadok ich iba prevzal. Najdôležitejším prvokom v tejto sfére, ktorý nie je priamo upravovaný legislatívou EÚ, je poskytovanie lekárenskej starostlivosti a využívanie systému verejného zdravotného poistenia v tejto oblasti.

Hlavným ciel’om príspevku je poukázat' na vybrané problémy, ktoré sa spájajú s postavením prevádzkovatela lekárne a jeho povinnostami, ktoré mu vyplývajú zo zákona o liekoch a s ktorými sa musí ako prevádzkovatel' lekárne vysporiadat'. Táto oblast' podnikania je pomerne prísne regulovaná a preto je potrebné byt’ oboznámený s príslušnými právnymi predpismi. Príspevok z právno-teoretického hl'adiska rieši viaceré otázky upravené v zákone o liekoch, či vyhláške o správnej lekárenskej praxi.

Keywords retail pharmacy-Medicines Act-pharmacy-pharmaceutical care 


\section{INTRODUCTION}

Right to protection of health is guaranteed through the provision of Art. 40 of the Constitution of the Slovak Republic, ${ }^{1}$ which applies to every natural person, that is, to every individual human being. This right is considered to be a human right directly related to the right to life since protection of health itself is an indispensable precondition of an individual's existence.

In the most general sense though, this right is regulated in Art. 12 of the International Covenant on Economic, Social and Cultural Rights ${ }^{2}$, according to which, states recognize the right of every individual to achieve the highest possible level of physical and mental health.

The aim of the Medicines Act $2011^{3}$ is to optimize wording of the law in relation to the medicines and medical devices, which until the inception of the Medicines Act 2011, were regulated through the previous Medicines Act 1998. ${ }^{4}$ Due to numerous changes, further amendments appeared to be inadequate and confusing; therefore, the legislator acted upon a motion of the Government of the Slovak Republic and enacted a completely new law, which should comprehensively address the issue, that is, to regulate manipulation of medicines and medical devices in a more lucid and transparent way. ${ }^{5}$

A large part of the areas that are covered by the Medicines Act 2011 is harmonized through the European Union (EU) legislation referred to in the compatibility clause. Based on the legal documents of the EU, the Medicines Act 2011 already contains the harmonized requirements for pharmaceutical testing, non-clinical (toxicological-pharmacological) testing and clinical trials of drugs for human and veterinary use, the registration of medicinal products for human and veterinary use, the manufacture and wholesale distribution of medicines for human and veterinary use as well as requirements for supervision over medicinal products for human and veterinary use. The Medicines Act 2011 also addresses the issue of medical devices for clinical testing, conformity

1 Zákon č. 460/1992 Zb. Ústava Slovenskej republiky v znení neskorších predpisov [Constitution of the Slovak Republic]

2 International Covenant on Economic, Social and Cultural Rights was enacted in December 19, 1966 and in force in Slovakia since March 23, 1976. It was published in the Collection of Acts as Vyhláška ministra zahraničných vecí č. 120/1976 Zb. z 10. mája 1976 o Medzinárodnom pakte o občianskych a politických právach a Medzinárodnom pakte o hospodárskych, sociálnych a kultúrnych právach, v znení Oznámenia Federálneho ministerstva zahraničných vecí č. 196/1991 Zb. o prijatí Opčného protokolu k Medzinárodnému paktu o občianskych a politických právach [International Covenant on Economic, Social and Cultural Rights].

3 Zákon č. 362/2011 Z. z. o liekoch a zdravotníckych pomôckach a o zmene a doplnení niektorých zákonov v znení neskorších predpisov [Medicines Act 2011]

4 Zákon č. 140/1998 Z. z. o liekoch a zdravotníckych pomôckach, o zmene zákona č. 455/1991 Zb. o živnostenskom podnikaní (živnostenský zákon) v znení neskorších predpisov a o zmene a doplnení zákona Národnej rady Slovenskej republiky č. 220/1996 Z.z. o reklame, v znení neskorších predpisov [Medicines Act 1998].

5 Dôvodová správa k zákonu o liekoch, všeobecná čast' [Explanatory Note]. http://www.nrsr.sk/web/Default.aspx?sid=zakony/zakon\&MasterlD=3740 cited on January 12, 2015 assessment of medical devices, registration of producers of medical devices and supervision over medical devices.

However, there are areas that are not harmonized through the EU legislation, since they fall within the exclusive competence of the individual Member States; in particular, providing pharmaceutical care, prescription of medicines as well as medical devices for human and veterinary use.

Providing pharmaceutical care is considered to be a business venture meaning that beside the promotion of public health and wellbeing, one of the aims of the holder of license for providing pharmaceutical care is to generate profit. Even though this is implicitly understood, the legislator has put severe restraints on methods of generating profit, especially in relation to the pharmaceutical care fully or partially covered through public health insurance system and to the so-called 'Prescription Only Medicines'.

There are other differences when comparing pharmacy business with other forms of commercial dealings, even in relation to proprietary rights to goods bought and sold in a pharmacy. Generally, the rights of an owner are regulated by provisions of Art. 123 of the Civil Code, ${ }^{6}$ which represents the 'lex generalis' of the private law (Lazar et al., 2006). This code guarantees that the owner is entitled, within the bounds of the law, to hold the object of his ownership, make use of it, enjoy its fruits and profits and dispose of it as he sees fit. However, this principle is renounced by the provisions of the Medicines Act 2011, which state that acquisition of title to medicines does not entitle to make use of them in other ways than stipulated by this act.

Due to negative experiences during effectiveness of the Medicines Act 1998, the legislator has set out to prevent perceived extensive corrupt behavior in pharmaceutical environment. New anti-corruption measures include prohibition for the holder of license for providing pharmaceutical care to grant or receive discounts in kind, or to personally or through other persons grant, offer or promise to a patient a pecuniary performance or a non-monetary performance, benefits or gifts of a proprietary or nonproprietary nature in relation to dispensation of a medicine for human use that is defined as a 'Prescription Only Medicine', as well as in relation to dispensation of dietetics that is on a categorized list of dietetics, ${ }^{7}$ or dispensation of a medical devices that is on a categorized list of medical devices, ${ }^{8}$ if they are being paid for on the basis of public health insurance. ${ }^{9}$ Identically, the holder of license for providing pharmaceutical care is prohibited to participate in non-professional events funded, sponsored or otherwise, directly or indirectly,

6 Zákon č. 40/1964 Zb. občiansky zákonník v znení neskorších predpisov [Civil Code]

7 Zákon č. 363/2011 Z.z. o rozsahu a podmienkach úhrady liekov, zdravotníckych pomôcok a dietetických potravín na základe verejného zdravotného poistenia a o zmene a doplnení niektorých zákonov v znení neskorších predpisov [Medicines' Payment Scope Act 2011] - Art. 59

8 See provisions of Art. 31 of the Medicines' Payment Scope Act 2011

9 This does not affect the provisions of Art. 89 of the Medicines' Payment Scope Act 2011 
financially or materially assisted by a holder of license for manufacturing of drugs, holder of license for wholesale dealing, or holder of registration of a medicine for human use, or by a third party on the basis of an agreement entered into with any of the aforementioned subjects. Furthermore, the holder of licence should not in any form, directly, indirectly or through a third party, incite, encourage or otherwise affect physician in prescribing medicine for human use, medical devices or dietetics.

\section{PHARMACEUTICAL CARE - LEGAL FRAMEWORK}

Pharmaceutical care in the Slovak Republic could be provided only in accordance with mandatory regulations of effective legislation and by a holder of license for providing pharmaceutical care, ${ }^{10}$ mainly a natural person running a community pharmacy. Provisions of Art.23 (1) of the Medicines Act 2011 exhaustively and in a great detail list all obligations of the holder of license for providing pharmaceutical care. The issue of providing pharmaceutical care is incorporated into Part Six of the Medicines Act 2011 starting with provisions in Art. 20, which in the first clause in an exhaustive list enumerates operations that are considered to be part of pharmaceutical care in the legal sense. The list is as follows:

- supplying, storage, preparation, control and dispensation of medicinal products, including Internet dispensations,

- supplying, storage and dispensation of medical devices, including Internet dispensations,

- fabrication of tailored medical devices and their dispensation,

- $\quad$ supplying and dispensation of dietetics in accordance with Act No. 152/1995 Coll. on Foods as amended,

- providing expert information and advice on medicines, medical devices and dietetics needed to provide quality health care under safe and rational drug therapy,

- control of medicines (Pharmacovigilance) and supervision of medical devices,

- $\quad$ supplying, storage and dispensation of supplementary products,

- implementation of physical and biochemical examinations aimed at primary prevention and monitoring of the efficacy and safety of drug therapy, which do not require further processing in a laboratory,

- $\quad$ substitution, sale and resale of medicines to the license holder for wholesale distribution of drugs or other holder of a license for providing pharmaceutical care.

License for providing pharmaceutical care is also necessary for hospital pharmacies that have clinical pharmacy departments, and are dealing with medicines for human use, preparation of sterile medicines for human use, preparation of cytostatics, radioactive medicines for human use, immunological

10 For procedures and conditions for obtaining a license for providing pharmaceutical care, see Part Two of the Medicines Act 2011 - Art. 6 through Art. 11 medicinal products for humans and control of medicines for human use, medical devices, dispensations of medicines, medical devices and dietetics to the public. In this context, it should be pointed out that the hospital pharmacy is an integral part of an institutional health care facility that, under orders, prepares and dispenses medicines for human use, medical devices and dietetics to the departments of its own institutional health care facility or some other institutional health care facility.

In particular, it should be noted that if an oncology clinic is part of such institutional health care facility, it must have an established department for the preparation of cytostatics. The Medicines Act 2011 allows the hospital pharmacy to have a department for dispensing of medicines, medical devices and dietetics to the public. In such a case, hospital pharmacy can not only provide these to the public but it can also charge for it the price of business or brokerage operation. ${ }^{11}$

Identically, the license for providing pharmaceutical care is also necessary for a community pharmacy, a branch of community pharmacy, a dispensary of medical devices, a dispensary of orthopaedic-prosthetic aids, as well as for a dispensary of audio-prosthetic aids. For the community pharmacy, the Medicines Act 2011 in regulations of a mandatory nature defines obligations related to providing pharmaceutical care, including individual preparation of medicines for the public and also for the outpatient health care facility and institutional health care facility in case they do not have a hospital pharmacy of their own. Community pharmacy is also obliged to dispense medicines, medical devices and dietetics to the health care provider on the basis of an order from the health care provider or from a health insurance company provided the medicine for human use or medical devices was procured by the health insurance company in accordance with a special legislation. ${ }^{12}$

There are special conditions set by the Medicines Act 2011 for a branch of community pharmacy, which could be found by the holder of license for providing pharmaceutical care exclusively in a municipality where there is no established community pharmacy and in a municipality that is located on the territory of the Autonomous Region which has issued the license for providing pharmaceutical care. The branch of community pharmacy itself can be providing pharmaceutical care for a shorter period of time than is the established weekly working time (Trelová \& Peráček, 2013), it does not have to provide individual preparation of medicines or emergency pharmacy services. The name or business name of community pharmacy, branch of community pharmacy and hospital pharmacy must include designation 'Pharmacy'. Other persons, both natural as well as legal, are expressly prohibited by the legislature to use or have in its name or

11 Zákon Národnej rady Slovenskej republiky č. 18/1996 Z. z. o cenách v znení neskorších predpisov [Prices Act 1996] - see Art. 2 (2)

12 Zákon č. 581/2004 Z. z. o zdravotných poistovniach, dohlade nad zdravotnou starostlivostou a o zmene a doplnení niektorých zákonov v znení neskorších predpisov [Health Insurance Companies Act 2004] 
business name the word 'pharmacy' including its translations in other languages. ${ }^{13}$

The task of dispensary of medical devices is to dispense medical devices on the basis of a medical voucher. Dispensary of orthopaedic-prosthetic aids is tasked, on the basis of a medical voucher, to individually fabricate, repair and dispense orthopaedic-prosthetic aids. Dispensary of audioprosthetic aids on the basis of a medical voucher individually fabricates, repairs and dispenses audio-prosthetic aids. Further, provisions of Art. 20 (10) of the Medicines Act 2011 negatively defines pharmaceutical care, that is, what is not pharmaceutical care in the legal sense, such as preparation of transfusion medicines, autovaccines and individual preparation of drugs for innovative treatment.

\section{PHARMACEUTICALCARE AND HEALTH INSURANCE COMPANIES}

The relationship between pharmaceutical care providers and health insurance companies is mostly of economic nature but is strictly governed by legislature with minimum of contractual freedom as opposed to other business relationships governed by, for example, Commercial Code ${ }^{14}$. The primary sources of legal provisions in this area are the Health Insurance Companies Act 2004 and the Act No. $363 / 2011$ Coll. on the Scope and Terms of Payment for Medicines, Medical Devices and Dietetics on the Basis of Public Health Insurance and on change and amendment of certain acts, as amended in collaboration with the Medicines Act 2011. When providing pharmaceutical care, the holder of license must observe all obligations set for him in provisions of Art. 23 (1) of the Medicines Act 2011, including provisions concerning economic side of the pharmacy business. For example, when a physician marks on a prescription or on a medical voucher a note 'paid by the patient', the holder of license for providing pharmaceutical care is entitled to collect financial payment for dispensation of a medicine, Medical Devices or dietetics from the patient, even though otherwise, he would be entitled to payment from a health insurance company in accordance with the Act No. 363/2011 Coll. on the Scope and Terms of Payment for Medicines, Medical Devices and Dietetics on the Basis of Public Health Insurance and on change and amendment of certain acts, as amended. When providing pharmaceutical care fully or partially covered through public health insurance, the holder of license for providing pharmaceutical care is required to have a valid contract on providing pharmaceutical care with a health insurance company of the policyholder. This contract must be in writing in duration for at least twelve months and it must include essential elements, which are designation of the parties to the contract, extent of the provided health care as

13 Provision of Art. 20 (6) of the Health Insurance Companies Act 2004 14 Zákon č. 513/1991 Zb. obchodný zákonník v znení neskorších predpisov [Commercial Code] well as maturity of payment for the provided health care in case the parties have agreed on a different set of rules than instituted in provisions of Art. 8 (2) of the Health Insurance Companies Act 2004 according to which the maturity of payment for the provided health care is 30 days from the day of delivery of the accountable receipt, unless the contractual parties have agreed on something else.

During the time period from issuing of the license for providing pharmaceutical care until the validity of the contract on providing pharmaceutical care with a health insurance company, the holder of the license for providing pharmaceutical care is permitted to provide pharmaceutical care fully or partially covered through public health insurance to the policyholders of the health insurance company in question but this time period, that is, period when there is no valid contract, could not legally be longer than six months. The health insurance company is obliged to submit a draft contract to the holder of the license for providing pharmaceutical care at his/her request no longer than one month after the request for entering into contract on providing pharmaceutical care was delivered. Further five months allowed by the Health Insurance Companies Act 2004 could be used for negotiation of individual terms of the contract.

To terminate the contract on providing pharmaceutical care by a unilateral act, that is, by renunciation or withdrawal from a contract is entitled only an aggrieved party to the contract in case the other contractual party has breached terms of the contract. In such a case, the renunciation period is one month starting from the first of the month following the month during which renunciation was delivered to the other contractual party and the contract itself terminates only after expiry of the renunciation period. As an imperfection of the Health Insurance Companies Act 2004 could be considered the fact that it does not require the renunciation of the contract on providing pharmaceutical care to be done in writing; thus creating considerable room for potential litigations to determine the invalidity of renunciation.

Withdrawal from a contract is as well as the renunciation a unilateral act regulated, for example, by provisions of Art. 302 of the Commercial Code, ${ }^{15}$ which could be validly performed if legislature or contract itself allows for it in its stipulations. When withdrawing from a contract pursuant to provisions of the Commercial Code, the contract terminates ex nunc, that is, at the moment of performing the relevant legal act or better yet at the moment of the other contractual party receiving the notice of withdrawal, which means that all legal effects that occurred prior to the termination of the contract are retained (Ovečková et al., 2005). This regulation is significantly different from the regulation of withdrawal, or cancellation of a contract in accordance with provisions of Art. 48 of the Civil Code ${ }^{16}$. When implementing civil legislation, the contract

15 Zákon č. 513/1991 Zb. obchodný zákonník v znení neskorších predpisov [Commercial Code]

16 Zákon č. 40/1964 Zb. občiansky zákonník v znení neskorších predpisov [Civil Code] 
terminates ex tunc, that is, the contract is null and void from its inception, which means that there are no legal effects as if the contract was never entered into (Lazar et al., 2006).

If the holder of license for providing pharmaceutical care commits a breach of the obligations stipulated by legislature, such as to maintain a proper and in accordance with the true stock recorded by piece of medicines, medical devices and dietetics and to make the system of stock recorded by piece accessible on request to the health insurance company so that the health insurance company can effectively check the accuracy of prescription and dispensation, the relevant health insurance company is entitled to withdraw from a contract on providing pharmaceutical care with such a holder of license. In such a case, the contract on providing pharmaceutical care terminates the moment the holder of license for providing pharmaceutical care receives a written notice of withdrawal containing reason for performing this legal act from the health insurance company.

\section{SPECIFIC STAFFING REQUIREMENTS FOR PROVIDING PHARMACEUTICAL CARE}

ONE of the most important conditions for providing pharmaceutical care is proper staffing. Institutional health care facility may provide pharmaceutical care in a hospital pharmacy only if, in addition to the general requirements stipulated in Art. 3 through Art. 5 of the Medicines Act 2011, it has appointed a professional representative, who meets the requirements for professional competence. It has to be a natural person, who has received a master's degree in the field of study 'pharmacy' and has professional practical experience of at least five years in a community pharmacy or a hospital pharmacy or has obtained a specialization diploma in the specialization field 'retail pharmacy'.

A natural person, who has received a master's degree in the field of study 'pharmacy' and has professional practical experience of at least five years in a community pharmacy or a hospital pharmacy or has obtained a specialization diploma in the specialization field 'retail pharmacy' is allowed to provide pharmaceutical care in a community pharmacy. Pharmaceutical care could be provided by a natural person, who does not meet the abovementioned requirements for professional competence or a legal person in case there is an appointed professional representative that meets all the legal requirements for professional competence.

Provisions of Art. 25 of the Medicines Act 2011 determine conditions of eligibility based on qualifications for persons that directly dispense medicines for human use and medical devices to patients. Medicines for human use could be dispensed only in hospital pharmacies, community pharmacies and branches of community pharmacies. Authorized person could be only a natural person, that is, individual, who has received a master's degree in the field of study 'pharmacy. A natural person, who has not received aforementioned degree but who has finished studies at a secondary school of health care in the field of study 'pharmaceutical laboratory technician' and has obtained a specialization diploma in the specialization field 'retail pharmacy' is also entitled to dispense medicines for human use, but only those that could be dispensed as an overthe-counter medicines.

Legal requirements for staffing are not so strict with providing pharmaceutical care in a dispensary of medical devices, a dispensary of orthopaedic-prosthetic aids and a dispensary of audio-prosthetic aids in the sense that a master's degree in the field of study 'pharmacy' of the professional representative is not strictly necessary since these activities could be provided by a secondary educated person in the relevant field. Pharmaceutical care could not, however, be provided by a natural person - a physician and a dentist - who provides a health care on the basis of a license for practicing independent medical practice ${ }^{17}$ at any other place than in a health care institution either based on a license for operating a health care institution or within employment relations to the health care provider.

Legislature in force and effective as amended defines the term 'appropriate pharmaceutical practice' as a set of requirements for material and spatial equipment, as well as requirements for staffing to ensure professional providing pharmaceutical care when preparing, controlling, storing and dispensing medicines and when providing information about them, when fabricating, storing and dispensing medical devices as well as when storing and dispensing dietetics. Pursuant to the delegating provision of the Medicines Act 2011, ${ }^{18}$ the Ministry of Health of the Slovak Republic as a central state administration body for the sector of health protection satisfied its legal obligation and on March 21, 2012 has issued an Appropriate Pharmaceutical Practice Regulation 2012, ${ }^{19}$ which became effective on May 15, 2012.

Staffing of a pharmacy and a dispensary of medical devices is regulated by provisions of Art. 21 through Art. 24 of the Appropriate Pharmaceutical Practice Regulation 2012. The head of pharmacy is a pharmacist, who is a holder of license for providing pharmaceutical care in a community pharmacy or in a branch of community pharmacy, or who is a professional representative of the holder of license for providing pharmaceutical care in a community pharmacy or in a branch of community pharmacy or in a hospital pharmacy. Along with it, he/she must be a member of a commission for rational pharmacotherapy and drug policy, a commission for anti-infective therapy and rational antibiotic policy and an ethics committee of a relevant institutional health care provider.

17 Zákon č. 578/2004 Z. z. o poskytovateloch zdravotnej starostlivosti, zdravotníckych pracovníkoch, stavovských organizáciách v zdravotníctve a o zmene a doplnení niektorých zákonov v znení neskorších predpisov [Health Care Providers Act 2004] - see provisions of Art. 10

18 Art. 141 (1/a) of the Medicines Act 2011

19 Vyhláška Ministerstva zdravotníctva Slovenskej republiky č. 129/2012 Z. z. o požiadavkách na správnu lekárenskú prax [Appropriate Pharmaceutical Practice Regulation 2012] 
Other professional work activities, specialized work activities and certified work activities occurring while providing pharmaceutical care in a hospital pharmacy, in a community pharmacy or in a branch of community pharmacy must be carried out by pharmacists, technicians for medical devices and pharmaceutical laboratory technicians in accordance with a by-law ${ }^{20}$ and with the latest knowledge of science and technology. Other, less skilled activities are being performed by economic and administrative employees (Peráček, Tomáš 2012), orderlies, cleaners and employees performing odd jobs.

Provisions of Art. 22 (4) of the Appropriate Pharmaceutical Practice Regulation 2012 addresses the issue of practical training and subsequent creativity of the next generation since it allows students in the master's program in the field of study 'pharmacy' as well as other student of pharmaceutical faculty or of the secondary school of health care in the field of study 'pharmaceutical laboratory technician' to perform their required professional training under the professional supervision of the head of pharmacy or of an appointed pharmacist in a hospital pharmacy, or in a community pharmacy, or in a branch of community pharmacy.

Finally, it should be noted that the number of health care workers employed in a hospital pharmacy is set in a much stricter manner than in a community pharmacy or in a branch of community pharmacy. ${ }^{21}$ Same set of rules apply though in the matter of identification of employees, who are required to wear an identification containing name and surname, position and title when providing pharmaceutical care in a pharmacy.

\section{SPECIAL REQUIREMENTS FOR INTERNET ${ }^{22}$ DISPENSATION}

Special requirements for Internet dispensation are stipulated in the provisions of Art. 22 of the Medicines Act 2011. According to the legal wording, Internet dispensation is a dispensation of a medicine or of medical devices based on an electronic order form published on the webpage of a community pharmacy or a dispensary of medical devices (hereinafter only as 'Internet dispensation') all the while the

\footnotetext{
20 Nariadenie vlády Slovenskej republiky č. 296/2010 Z. z. o odbornej spôsobilosti na výkon zdravotníckeho povolania, spôsobe d’alšieho vzdelávania zdravotníckych pracovníkov, sústave špecializačných odborov a sústave certifikovaných pracovných činností v znení neskorších predpisov [Professional Competence Decree 2010] - see Art. 10, Art. 37 and Art. 41

21 See Art. 22 of the Appropriate Pharmaceutical Practice Regulation 2012

22 Internet is a worldwide network - a interconnection of subscriber stations on a global scale that functions on the principle of connection through transmission communication protocols TCP/IP. These protocols are mediators of communication of different computers, systems with different technical equipment and networks with different parameters. These protocols facilitate trouble-free communication and transfer of information from anywhere to anywhere on Earth within seconds. Individual local networks, so-called LAN (Local Area Network) are mutually interconnected into extensive networks, so-called WAN (Wide Area Network) and together they form a huge virtual environment with millions of participants who then can communicate directly with one another - off-line or on-line. (Gregušová, Daniela et al. 2005).
}

goods thus dispensed could only be registered medicines for human use as well as medicines for veterinary use that are not in the category'Prescription-Only-Medicines' medical devices that meet the requirements of the marketing authorization pursuant to special legal regulations ${ }^{23}$ except for active implantable medical devices, diagnostic medical devices in vitro, medical devices of the III. group or IIb. Group. ${ }^{24}$. This form of dispensation could only be provided by a holder of license for providing pharmaceutical care in a community pharmacy or in a dispensary of medical devices.

Holder of license for providing pharmaceutical care in a community pharmacy or in a dispensary of medical devices, who is also providing Internet dispensation is, according to the Medicine Act 2011, obliged to publish and keep during the whole period of providing Internet dispensation information (Peráček, Tomáš 2013) about Internet dispensation, including limitations, offered goods - medicines as well as complementary goods, their price, additional costs related to Internet dispensation and information about the total price for the ordered goods, about the time period during which he/she is bound by his/her offer, including the prices, as well as about the right to withdraw from the contract on Internet dispensation. Furthermore, the provider is encumbered with a duty to inform about a name and surname and place of residence if the Internet dispensation is provided by a natural person. If the Internet dispensation is provided by a legal entity then the duty to inform applies to the name or business name, registered office, legal form and identification number, as well as to name and surname and place of residence of a person/s, who is/are authorized representative/s (Gregušová, Daniela - Susko, Boris 2004).

It is also necessary to ensure shipment (Peráček, Tomáš 2014) containing medicines or medical devices in such a way so as to preserve quality of medicines or medical devices, even in case the shipment itself is carried out by a third party. Provider of Internet dispensation is obliged to enable the customer to return the medicines or medical devices after their claim in such a manner that will not cause the cost to the customer. Returned medicines and medical devices become unusable and according to legislature, they are considered to be waste whose generator is the holder of license for providing pharmaceutical care in a community pharmacy or in a dispensary of medical devices who is also providing Internet dispensation. The license holder is obliged to ensure

\footnotetext{
23 Zákon č. 264/1999 Z. z. o technických požiadavkách na výrobky a o posudzovaní zhody a o zmene a doplnení niektorých zákonov v znení neskorších predpisov [Technical Requirements Act 1999] - see Art. 4 24 See Nariadenie vlády Slovenskej republiky č. 582/2008 Z. z. z 26. novembra 2008, ktorým sa ustanovujú podrobnosti o technických požiadavkách a postupoch posudzovania zhody zdravotníckych pomôcok v znení Nariadenia vlády Slovenskej republiky č. 215/2013 Z. z. z 26. júna 2013; Nariadenie vlády Slovenskej republiky 527/2008 Z. z. z 12. novembra 2008, ktorým sa ustanovujú podrobnosti o technických požiadavkách a postupoch posudzovania zhody aktívnych implantovatel'ných zdravotníckych pomôcok; Nariadenie vlády Slovenskej republiky 569/2001 Z. z. z 13. decembra 2001, ktorým sa ustanovujú podrobnosti o technických požiadavkách a postupoch posudzovania zhody diagnostických zdravotníckych pomôcok in vitro v znen neskorších predpisov
} 
disposal of such waste at his own expense in accordance with provisions of Art. 74 of the Medicines Act 2011, according to which, medicines for human use should be disposed according to the special regulation. ${ }^{25}$

Further special requirements and provisions are applicable on the issue of Internet dispensation of medicines and medical devices for other Member States of the EU. As is apparent from the principles of European legislature, it is required for them to meet requirements of the Member State to which they are being sent. Slovak legislature reflects this in provisions of Art. 22 (4) of the Medicines Act 2011. Internet dispensation to the Slovak Republic is possible exclusively from the Member States of the EU, which means a legal prohibition of import of drugs through Internet dispensation from any countries that are not members of the EU. This measure is justified on the grounds of existence of the Regulation (EC) No. 726/2004 of the European Parliament and of the Council of March $31,2004^{26}$ that is without further need of legislative action applicable in all Member States and therefore, sets the same standards and requirements that have to be met in this area in the whole of EU.

\section{CONCLUSION}

Legal regulation of operating pharmacies in the Slovak Republic covers a broad scope of issues and is quite extensive. Through concerted legislative effort, the legislator had tried to set rules that would make the legal environment in this sector more transparent and easier to navigate through. In some areas, the rules were set by the legislature of the EU and the Slovak legislature only adapted them. The most important aspect of legal regulation in this sphere that is not completely regulated by the EU legislature is providing pharmaceutical care and usage of the public health insurance system with regard to providing pharmaceutical care. The scope of the study did not allow for a too-deep probe and it was not its aim. The aim was to present few select insights into issues that are fairly strictly regulated and provide overview of legal basis on which to study and analyze the realities of operating pharmacies and providing pharmaceutical care in the Slovak Republic.

\section{References}

[1] Gregušová, Daniela - Susko, Boris: Elektronický obchod a jeho právna úprava v Slovenskej republike (zákon NR SR č. 22/2004 Z. z. o elektronickom obchode) In: Justičná revue. - Roč. 56, č. 11 (2004), s. 1226-1240

[2] Gregušová, Daniela a kol.: Právo informačných a komunikačných technológii. Bratislava 2005

[3] Lazar, Ján et al.: Občianske právo hmotné, 1. čast'. Bratislava, lura Edition; 2006

[4] Ovečková, Ol'ga et al.: Obchodný zákonník. Komentár 1. čast'. Bratislava, lura Edition, 2005

[5] Peráček, Tomáš: Právo zamestnanca na súdnu ochranu a jeho úprava v právnom poriadku Slovenskej republiky. In. Zákon č.
311/2001 Z. z. Zákonník práce: desat' rokov aplikačnej praxe (2001-2011). - Bratislava: Univerzita Komenského v Bratislave, Právnická fakulta, 2012. s. 73-81

[6] Peráček, Tomáš: Medzinárodnoprávne garancie prístupu $k$ informáciám. In: Súčasné trendy a problémy $v$ manažmente [elektronický zdroj] - Bratislava: Univerzita Komenského v Bratislave, 2013. S. 186-198 [CD-ROM]

[7] Peráček, Tomáš: Zasielatel'ská zmluva. In: Obchodné právo pre manažérov Obchodné záväzkové vzt’ahy - Bratislava. Univerzita Komenského v Bratislave, 2014. s. 120-128

[8] Trelová, Silvia - Peráček, Tomáš: Pracovné právo pre manažérov. Bratislava, Univerzita Komenského v Bratislave; 2013.
[1] Vyhláška ministra zahraničných vecí č. 120/1976 Zb. z 10. mája 1976 o Medzinárodnom pakte o občianskych a politických právach a Medzinárodnom pakte o hospodárskych, sociálnych a kultúrnych právach, v znení Oznámenia Federálneho ministerstva zahraničných vecí č. 196/1991 Zb. o prijatí Opčného protokolu k Medzinárodnému paktu o občianskych a politických právach [International Covenant on Economic, Social and Cultural Rights]

[2] Regulation (EC) No. 726/2004 of the European Parliament and of the Council of March 31, 2004 laying down Community procedure for authorization and supervision of medical products for human and veterinary use and establishing a European Medicines Agency

[3] Zákon č. 460/1992 Zb. Ústava Slovenskej republiky v znení neskorších predpisov [Constitution of the Slovak Republic]

[4] Zákon č. 362/2011 Z. z. o liekoch a zdravotníckych pomôckach a o zmene a dopInení niektorých zákonov v znení neskorších predpisov [Medicines Act 2011]

[5] Zákon č. 140/1998 Z. z. o liekoch a zdravotníckych pomôckach, o zmene zákona č. 455/1991 Zb. o živnostenskom podnikaní (živnostenský zákon) v znení neskorších predpisov a o zmene a dopInení zákona Národnej rady Slovenskej republiky

25 Zákon č. 223/2001 Z. z. o odpadoch a o zmene a doplnení niektorých zákonov v znení neskorších predpisov [Wastes Act 2001]

26 Regulation (EC) No. 726/2004 of the European Parliament and of the Council of March 31, 2004 laying down Community procedure for authorization and supervision of medical products for human and veterinary use and establishing a European Medicines Agency 
č. 220/1996 Z. z. o reklame, v znení neskorších predpisov [Medicines Act 1998]

[6] Dôvodová správa k zákonu o liekoch, všeobecná čast’ [Explanatory Note]

[7] Zákon č. 40/1964 Zb. občiansky zákonník v znení neskorších predpisov [Civil Code]

[8] Zákon č. 363/2011 Z. z. o rozsahu a podmienkach úhrady liekov, zdravotníckych pomôcok a dietetických potravín na základe verejného zdravotného poistenia a o zmene a doplnení niektorých zákonov v znení neskorších predpisov [Medicines' Payment Scope Act 2011]

[9] Zákon Národnej rady Slovenskej republiky č. 18/1996 Z. z. o cenách v znení neskorších predpisov [Prices Act 1996]

[10] Zákon č. 581/2004 Z. z. o zdravotných poistovniach, dohl'ade nad zdravotnou starostlivostou a o zmene a doplnení niektorých zákonov v znení neskorších predpisov [Health Insurance Companies Act 2004]

[11] Zákon č. 513/1991 Zb. obchodný zákonník v znení neskorších predpisov [Commercial Code]

[12] Zákon č. 578/2004 Z. z. o poskytovateloch zdravotnej starostlivosti, zdravotníckych pracovníkoch, stavovských organizáciách v zdravotníctve a o zmene a doplnení niektorých zákonov v znení neskorších predpisov [Health Care Providers Act 2004]

[13] Zákon č. 264/1999 Z. z. o technických požiadavkách na výrobky a o posudzovaní zhody a o zmene a doplnení niektorých zákonov v znení neskorších predpisov [Technical Requirements Act 1999]
[14] Zákon č. 223/2001 Z. z. o odpadoch a o zmene a doplnení niektorých zákonov $\mathrm{v}$ znení neskorších predpisov [Wastes Act 2001]

- Nariadenie vlády Slovenskej republiky č. $296 / 2010$ Z. z. o odbornej spôsobilosti na výkon zdravotníckeho povolania, spôsobe d’alšieho vzdelávania zdravotníckych pracovníkov, sústave špecializačných odborov a sústave certifikovaných pracovných činností v znení neskorších predpisov [Professional Competence Decree 2010]

- Nariadenie vlády Slovenskej republiky č. 582/2008 Z. z. z. 26. novembra 2008 , ktorým sa ustanovujú podrobnosti o technických požiadavkách a postupoch posudzovania zhody zdravotníckych pomôcok v znení Nariadenia vlády Slovenskej republiky č. 215/2013 Z. z. z 26. júna 2013

- Nariadenie vlády Slovenskej republiky 527/2008 Z. z. z 12. novembra 2008, ktorým sa ustanovujú podrobnosti o technických požiadavkách a postupoch posudzovania zhody aktívnych implantovatelných zdravotníckych pomôcok

- Nariadenie vlády Slovenskej republiky 569/2001 Z. z. z 13. decembra 2001, ktorým sa ustanovujú podrobnosti o technických požiadavkách a postupoch posudzovania zhody diagnostických zdravotníckych pomôcok in vitro v znení neskorších predpisov

- Vyhláška Ministerstva zdravotníctva Slovenskej republiky č. 129/2012 Z. z. o požiadavkách na správnu lekárenskú prax [Appropriate Pharmaceutical Practice Regulation 2012] 